\title{
The Role of Omnichannel and Experiential Marketing to Build Brand Association in ZAP Clinic
}

\author{
Alfina $^{1 *}$; Marisya Mahdia Khoirina²; Muwahiddatul Ulya ${ }^{3}$ \\ ${ }^{1-3}$ Departemen Manajemen, Fakultas Ilmu dan Bisnis, Universitas Internasional Semen Indonesia \\ Kompleks PT. Semen Indonesia (Persero) Tbk, Jln. Veteran, East Java 61122, Indonesia \\ ${ }^{1}$ alfina@uisi.ac.id; ${ }^{2}$ marisya.khoirina@uisi.ac.id; ${ }^{3}$ muwahhidatululya@gmail.com
}

Received: $25^{\text {th }}$ January 2021/ Revised: $1^{\text {st }}$ March 2021/ Accepted: 22 ${ }^{\text {nd }}$ March 2021

How to Cite: Alfina, Khoirina, M. M., \& Ulya, M. (2021). The Role of Omnichannel and Experiential Marketing to Build Brand Association in ZAP Clinic. Binus Business Review, 12(3), 255-261. https://doi.org/10.21512/bbr.v12i3.6991

\begin{abstract}
The development of online commerce, popularly known as online stores, has rapidly changed people's lifestyles. Lately, online shopping trends do not mean that offline stores are no longer prioritized, especially in beauty clinics that sell their services and products. ZAP Clinic Indonesia is a beauty clinic focusing on offline and online sales to increase the company's brand equity. The research aimed to determine and analyze the effect of omnichannel and experiential marketing on brand association using the Customer-based Brand Equity (CBBE) method. The research applied a quantitative approach with a sample size of 101 respondents. The respondents were the consumers who had visited and tried the services and products of ZAP Clinic in Surabaya. The sampling technique was accidental sampling with a questionnaire as the instrument. Then, data were analyzed using the multiple regression analysis method to determine whether omnichannel and experiential marketing affected the brand association at ZAP Clinic. The results show that omnichannel and experiential marketing have a positive effect on brand association. Experiential marketing has a dominant value to create a stronger positive association. Moreover, omnichannel will boost the creation of brand association about ZAP Clinic through the marketing campaigns and delivering new experiences related to technology usage in skincare treatment.
\end{abstract}

Keywords: omnichannel retailing, experiential marketing, brand association

\section{INTRODUCTION}

Digital disruptions are a consumer-driven phenomenon (Matzler, Eichen, Anschober, \& Kohler, 2018). Technology is not the real disruptor. However, not being consumer-centric is the biggest threat to any business (Wirtz \& Daiser, 2018). Disruption starts with unhappy customers, not technology (Teixeira, 2019). The era of digital transformation has arrived, and many businesses have joined into this transformation. Digital transformation can bring more Return on Investment (ROI), higher efficiency, productivity, and the most important, a more satisfying customer experience.

One of the digital transformations that become the focus of many industries is how companies communicate with consumers (Ismail, Khater, \& Zaki, 2017). Technological developments change the behavior of customers and companies in their interactions (Hendriyani \& Chan, 2018). Because interaction and communication shift from traditional to digital way, many companies should follow that phenomenon.

The shifting of interaction and communication in the market has also changed consumers' attitudes and behaviors as they have more diverse choices (Moustakas, 2015). This situation is a challenge for retailers to survive amid future competition. The increasing public consumption of a product forces retailers to connect every channel with a combination of technology and local cultural trends to stay well connected with consumers. Moreover, retailers also need a strategy to maximize their offerings to match this new consumer behavior.

New consumer behavior is followed by the rapid increase of online shopping worldwide (Nabot, Garaj, \& Balachandran, 2014). In 2020, retail e-commerce worldwide amounted to US\$4,206 trillion and was projected to grow rapidly because of the COVID-19 pandemic. Figure 1 shows retail e-commerce worldwide. 


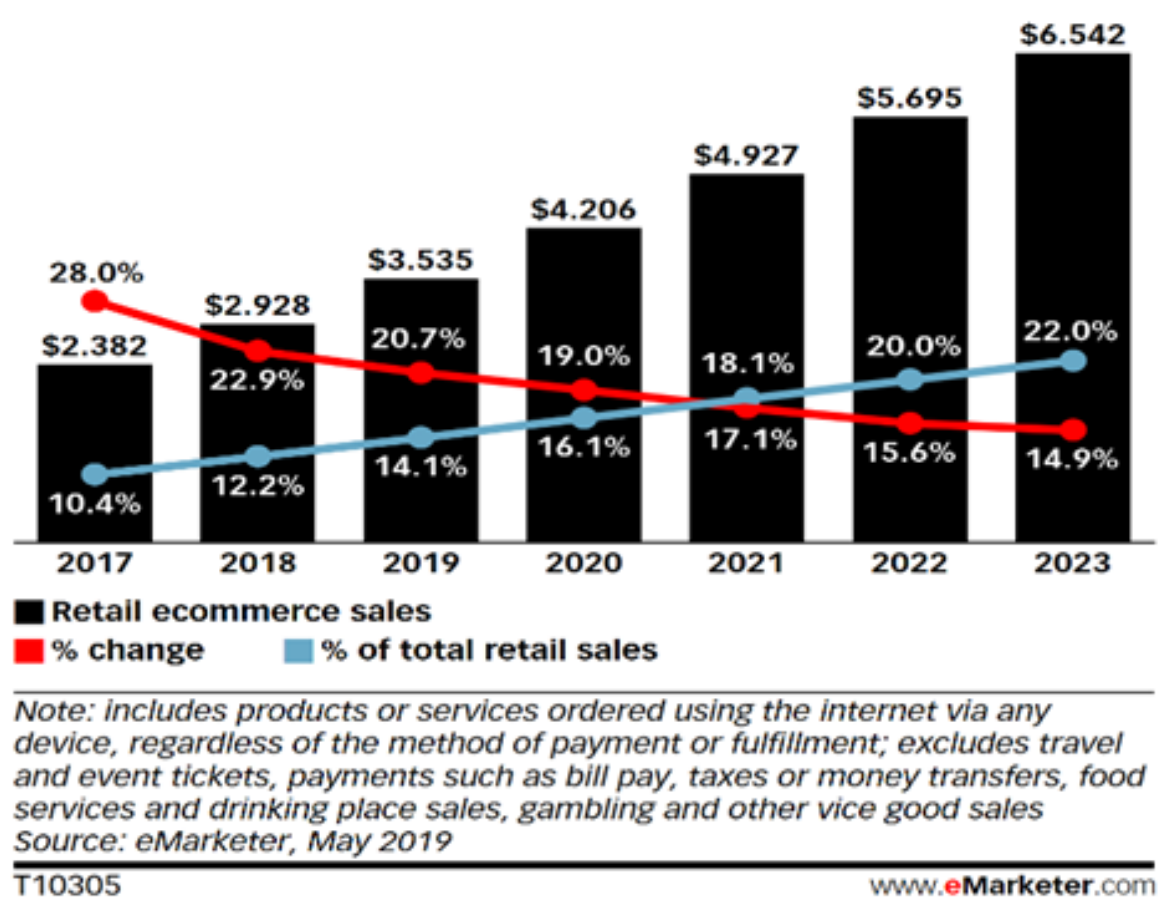

Figure 1 Retail E-Commerce Worldwide in 2017-2023

Accompanied by widespread e-commerce, retailers begin to create new channel systems to meet the changing market environments and innovative information technologies (Lee, 2020). The retailers need to create new integration in their distribution system to serve customers through multiple channels, such as the Internet, mobile website, social media, YouTube, and offline stores. The new integration also means that if a customer wants to buy the product or service, it will not matter anymore, whether online or offline. One of the ways that the retailers seek is the integration with omnichannel.

Omnichannel retailing refers to using a variety of channels to interact with consumers and satisfy their needs (Simone \& Sabbadin, 2018). From consumers' perspective, omnichannel has enabled them not only to purchase the products on the e-commerce but also check the available stock of the physical store (Hiraishi et al., 2016). For omnichannel consumers, the store experiential marketing they want is very different from the consumers in traditional retail. It is because the consumers already have an expectation. The moment the consumers walk through the shop door, they are far more prepared and know the products they want to see and expect to pay. They also expect the staff to know more and help them to make a final decision (Cook, 2014).

The more demanding consumers today make the retailers have a challenging position. Consumers are emotionally as well as rationally driven. Today, consumers take functional features and benefits, product quality, and positive brand image as a given.
They want something that dazzles their senses, touches their hearts, and stimulates their minds. Moreover, consumers want products or services that they can relate to their lifestyle (Cook, 2014).

More and more businesses have already applied the combination of omnichannel and experiential marketing strategies to forge experiential connections with consumers (Kumar, 2018). Experiential marketing is particularly relevant to building a strong customer-brand connection and increasing loyalty, word-of-mouth, and brand awareness (Shah, Rajper, Ghumro, \& Mahar, 2018). The experiential marketing strategy that becomes a concern in the research is a marketing strategy that emphasizes the five elements to provide a unique impression and experience to customers (Khan, 2016). First, it decides consumers' experience regarding product design, motivation to buy, and product quality (sense). Second, it determines consumers' feelings in the form of pride, satisfaction, and pleasure when using products (feel). Third, it finds out consumers' thoughts about experiences that are not obtained from other clinics and consumers' perceptions of the offered promotion (think). Fourth, it is regarding the experience in using a product or service (act). Fifth, it determines consumers' membership, social status, and interactions with the company (Relate).

Using modern and interactive media increasingly makes marketing strategies appear attractive to consumers. Several marketing strategies are recognized for their reliability and utilize technology to carry out more modern strategies. These methods 


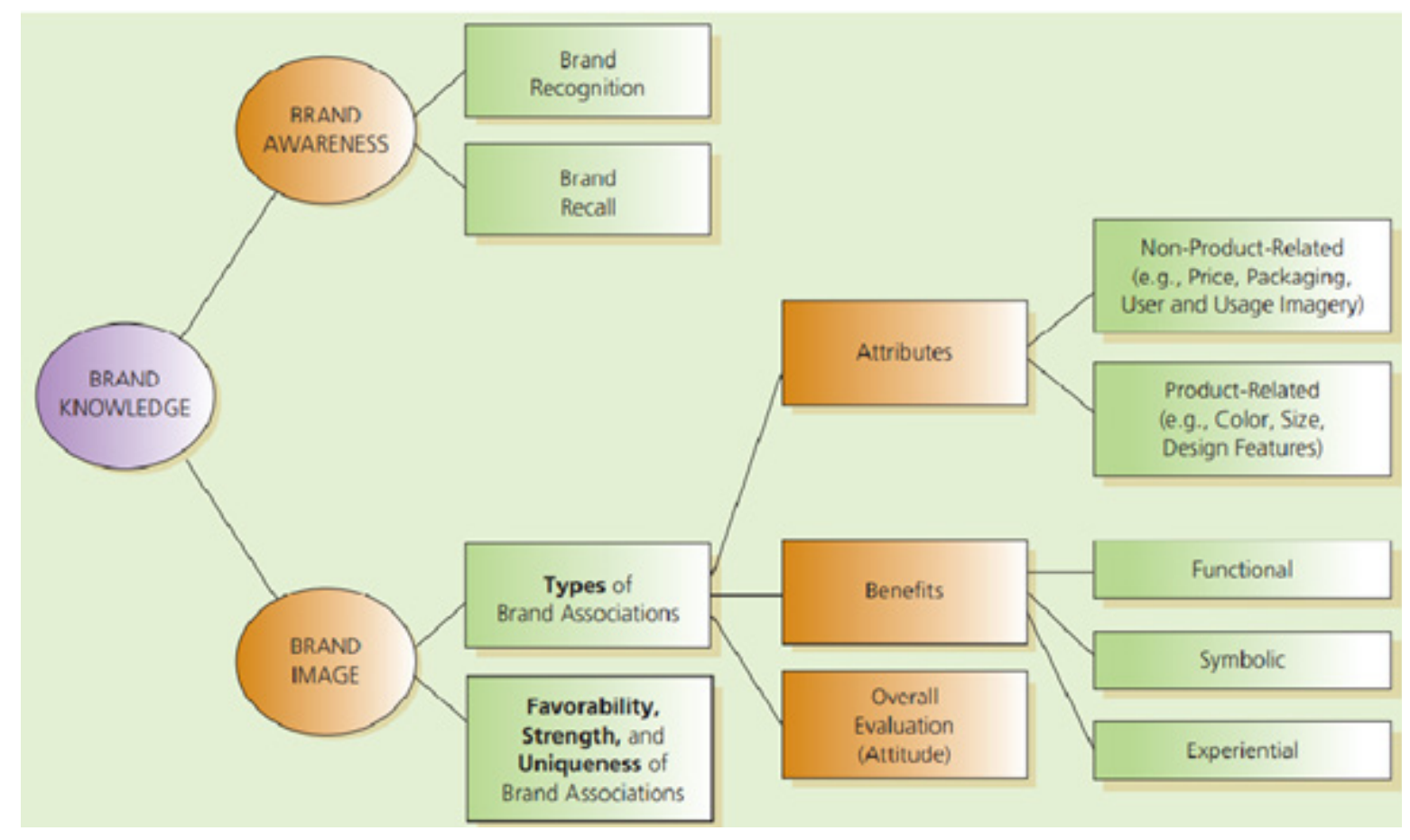

Figure 2 Customer-based Brand Equity (CBBE) Concept

are none other than attracting potential consumers in determining purchasing decisions for a product and forming a brand association that is expected to have a positive impact. The brand associations consist of a product attribute, intangible attribute, consumers' benefit, relative price, application, consumer, celebrity, lifestyle, product class, competitors, and country or geographic area (Keller, 2013). The brand association enables a company to differentiate its brand in the market. It can be proven as the key to competitive advantage (Ergin, Ozdemir, \& Ozsacmaci, 2006).

Forming a brand association can be done in various ways, from marketing activities, especially beauty retailers, to utilizing technology by implementing the omnichannel strategy. The strategy is a customer service feature by integrating all communication channels between the company and consumers. Then, it results in the same data shared in each channel (Yanuardi, Wahyudi, \& Nainggolan, 2016). The previous research shows that pharmaceutical companies using omnichannel in their marketing strategies can increase the number of consumers and easily provide insight into the brand by forming a channel of membership company (Kang, Majer, \& Kim, 2019). Another research conducted by Hasan and Hasan (2019) suggests that many distribution channels allow consumers to form brand associations for companies in Bangladesh easily.

Building a positive brand association is very important because it is the main part of building the brand image (Kim \& Chao, 2019). Brand image is defined as perception about a brand reflected by the cluster of associations that consumers connect to the brand name in memory. Thus, the brand association is the other informational node linked to the brand node in memory and contains the meaning of the brand for consumers. Although there is no fixed agreement on how to measure brand image, a way that is generally accepted is Consumer-based Brand Equity (CBBE) (Keller, 2013).

According to Keller (2013), CBBE is the different effect that a brand has on the consumers' responses to the marketing of that brand. In other words, it is the different effects that consumers have on a brand as a form of response to marketing activities. The CBBE model is created from the consumers' perspective to build brand equity to create a brand that they can recognize and have strong, preferred, and unique brand associations. A brand is said to have a high CBBE if the consumers give a positive reaction to a product, price, or communication when the brand is identified compared to the product without a brand. The key to creating brand equity is brand knowledge which consists of the dimensions of brand awareness and brand image. In CBBE Concept, after the brand image has been built, it should be combined with brand awareness to generating value to brand equity. Figure 2 shows the CBBE concept.

In Indonesia, Markplus Inc. in 2019 successfully held the first award related to omni-brands. This event shows the proof of the companies about the success of the marketing strategy, involving multichannel and omnichannel. In this era of connectivity technology, brands are challenged to remain relevant to the needs 
of the times, where brands must integrate online and offline (Syana, 2019).

ZAP Clinic is one of the brands that received awards from Marketeers in 2019 in the OmniBrand category. In the journey of this Omni-Brand, Marketing Journey is a new category because it has never existed before, especially in the beauty industry. The success achieved by ZAP Clinic departs from their success in defining, understanding, maintaining consumers' loyalty, and participating in implementing the omnichannel strategy that is its mainstay. In addition, the success of the ZAP Clinic, which can be said to be fast enough to hypnotize the Indonesian, is also because ZAP Clinic knows its main service very well. It is a service, so it must provide experience in every business activity to create lasting impressions on consumers, and they want to share the experience with others (Syana, 2019).

ZAP Clinic is a beauty clinic with a branch in Surabaya. It strives to meet consumers' needs by offering beauty treatments that favor using lasers for hair removal as a milestone in the initial business process of ZAP Clinic. Since 2009, Fadly Sahab, with a capital of IDR 50 million, has established a hair removal salon business from house to house. It provides services in the field of skin and hair care. The face treatment, body treatment, and hair treatment that are safe, healthy, and without side effects use natural ingredients, such as fruits, vegetables, tubers, and roots combined with modern technology. The services are done directly by doctors to provide many benefits and care for beauty (ZAP Clinic, 2020).

ZAP Clinic starts its strategy with improving Unique Selling Point (USP) consistently, from ZAP services to the used high-technology machines. After ZAP Clinic successfully builds a strong offline shop, it also applies an online strategy. ZAP Clinic utilizes various digital marketing strategies to provide a comfortable experience in outlets to the digital arena. Through social media, website, and ZAP application, customers can easily obtain information and make transactions. The ZAP application integrates all ZAP Clinic outlets in Indonesia so that consumers can see the schedule and service availability in real-time (Syana, 2019).

Based on the mentioned explanations, the research aims to measure how the shifting of the consumer behavior and the company's response by building omnichannel and experiential marketing strategy impacts the process of building brand association using the CBBE Concept. It is expected to know the role of experiential marketing and omnichannel in shaping the brand image through brand associations in the beauty industry.

\section{METHODS}

The research applies an associative quantitative method. This type of research aims to analyze a relationship between the independent and dependent variables. The population is the consumers who have visited and tried the services and products of ZAP Clinic in Surabaya. The sampling technique is an accidental sampling with a questionnaire as the instrument (Taherdoost, 2016). The research looks for samples based on account selection on the social media followers of the official ZAP Clinic account. Then, they are given the opening question to ensure that they have used ZAP Clinic before.

Based on the conditions, the research determines the number of samples with an unknown population. The number can be said to be in the infinite category by using the Lemeshow formula, as seen in Equation (1) (Lemeshow, Hosmer Jr, Klar, \& Lwanga, 1990). Through Equation (1), the number of samples to be taken is 101 .

$$
\mathrm{n}=\frac{z^{2} p(1-p)}{d^{2}}
$$

Where,

$\mathrm{n}=$ the amount of sample

$\mathrm{z}=$ score in level of confidence of $95 \%=1,96$

$\mathrm{p}=$ max estimation $=0,5$

$d=$ alpha $(0,10)$ or sampling error $=10 \%$

The measurement of variable instruments in quantitative research must meet several requirements to produce accurate measurement data. In the research, validity and reliability tests are used. Validity test is related to accuracy and measuring tools. The instrument is said to be valid if the instrument can measure exactly what is measured. The validity test is performed using the Pearson correlation method with a tolerable degree of error of $\alpha$ of $5 \%$. If the significant value obtained from each indicator is smaller than 0,05 , it is declared valid (Ghozali, 2016).

Meanwhile, the reliability test shows the extent to which the stability and consistency of the measuring devices are. It provides relatively consistent results if these measurements are repeated. A variable is said to be reliable if it provides a bigger Cronbach's Alpha value than 0,60 (Ghozali, 2016).

Next, multiple regression is applied to determine the influence between the independent variables (omnichannel and experiential marketing) and the dependent variable (brand association). Four indicators measure Omnichannel: consumers' channel experience, location-based strategy, operational capability, and technology data (Sugesti, Kusniawati, \& Prabowo, 2019). Meanwhile, experiential marketing uses five indicators: sense, feel, think, act, and relate. All variables are measured using a Likert scale (score one to five), ranging from strongly disagree, disagree, neutral, agree, to strongly agree.

\section{RESULTS AND DISCUSSIONS}

The 101 respondents answer the questionnaire and provide data for the research. About 77 respondents are female, while the rest are male respondents. The respondents' ages range from 15 to 46 years old. Most 
of the respondents are entrepreneurs, students, and civil servants. Then, 1 person or $1 \%$ is a student. Then, there are 29 people or $29 \%$ students, 18 people or $18 \%$ civil servants, and 42 people or $41 \%$ entrepreneurs. About 1 person or $1 \%$ is trader, and unemployed respondents are 10 or $10 \%$.

Then, for monthly income, most of the respondents have Rp3.000.000,00-5.999.999,00 (29 people or 28\%). Then, there are also Rp300.000,00-Rp999.999,00 (13 people or 13\%), Rp1.000.000,00-Rp2.999.999,00 (15 people or $15 \%$ ), and Rp6.000.000,00-Rp9.999.999,00 and > Rp10.000.000,00 (22 people or $22 \%$ for each category). It can be concluded that the most respondents' monthly incomes range from Rp3.000.000,00 to Rp5.999.999,00.

In the validity test, all question items have a calculated that r-value is greater than the r-table. Therefore, it can be said to meet the valid criteria based on the calculation. All question items from each variable have a greater calculated r-value than the r-table value $(0,361)$. Meanwhile, in the reliability test, all question items have a greater Cronbach's alpha value than 0,6 , so the measurement indicators in the research are reliable.

Table 1 The Result of Statistical Value

\begin{tabular}{lccc}
\hline \multirow{2}{*}{ Model } & \multicolumn{3}{c}{ Unstandardized Coefficients } \\
\cline { 2 - 4 } & $\beta$ & $\begin{array}{c}\text { Std. } \\
\text { Error }\end{array}$ & Sig. \\
\hline Constant & 9,288 & 2,814 & 0,001 \\
Omnichannel & 0,248 & 0,109 & 0,025 \\
Experiential Marketing & 0,662 & 0,061 & 0,000 \\
\hline
\end{tabular}

Using the SPSS program, the result shows that the statistical value of the t-test is greater than the t-table $(1,9844)$, and the significance is smaller than 0,05 . Table 1 shows the result of statistical value. It implies that omnichannel and experiential marketing have a significant effect on brand association. Then, from the standardized coefficients beta, it is salient that experiential marketing has a bigger value and a dominant effect on the brand association in the case of ZAP Clinic.

From the analysis, it is known that omnichannel and experiential marketing affect brand association at ZAP Clinic in Surabaya. These results are in line with research conducted by (Blom, Lange, \& Hess Jr, 2017). The previous research shows a similar result. Consumers currently have more than one social media account and find out products or services using these various platforms. The use of an omnichannel by a brand can mean convenience for its consumers. In that sense, it is easy to access channels to connect with a brand without requiring consumers to repeat data registration inputs because their data has been appropriately recorded in the system.
Omnichannel also means that the marketing campaigns carried out by a brand will also be more numerous and cross-channel. Repetition of such marketing campaigns will be stored in consumers' memory and will continue to get stronger because the frequency of exposure will be more frequent across all customers' touchpoints. That is how the omnichannel conducted by ZAP Clinic is created in the minds of consumers.

In experiential marketing, because the brand association is everything linked to consumers' mindset, marketers should create a marketing strategy that engages the consumer and creates a real-life experience that will be remembered. From the five experiential marketing indicators used in the research, most of the indicators that use the five senses, such as sense, feel, and act, show positive experiences when visiting ZAP Clinic. It means that ZAP Clinic has tried to indulge consumers' five senses starting from the interior design of each beauty clinic, the distinctive aroma in each ZAP Clinic outlet, to several other things that can create comfort for consumers. This strategy also affects other experiential marketing indicators, namely think and relate. Therefore, the ZAP Clinic image that is formed in consumers is a modern beauty clinic that offers products that are updated and in accordance with the needs of the urban lifestyle.

The result is supported by (Ebrahim, 2020). There is a significant relationship between consumers' experience views and brand association. Conducted in the Middle East (Arab), the marketing managers use experiential marketing because it can represent the consumers' experience in describing a brand verbally. With the experience that consumers have, they can evaluate the brand and make choices about the products or services that the company has. Thus, the brand experience can be considered an essential source of brand associations and organizations. The increase in brand association occurs because marketers can create a more positive experience. The consumers' experience shows their appreciation and love for the brand. The brand association is the main component of brand image in the CBBE concept (Świtała, Gamrot, Reformat, \& Bilińska-Reformat, 2018). It is known that brand image is a factor with a higher position than physical products. Hence, everything related to product attributes must be carefully reviewed.

ZAP Clinic is a brand focusing on activities in the service sector that the characteristics of a service business are unique. There are four characteristics: intangibility (services cannot be seen tested, tasted, felt, heard, or smelled before purchase), inseparability (service cannot be separated from the providers), variability (quality of service depends on who provide them, when, where, and how), and perishability (service cannot be stored for later sale or use). Service requires the help of tangible things to translate that kind of characteristic. Hence, a brand needs experiential marketing to ensure all ZAP Clinic promises to consumers (Kotler, 2016). The place, price, equipment, and communication material must indicate the service 
quality as claimed by the service provider (Polyakova $\&$ Mirza, 2015). Then, the physical setting of ZAP Clinic must suggest comfort and professional service. Its exterior and interior should have a cozy atmosphere, elegance, clear lines, and relaxing background music. Moreover, the therapist should be professional, welleducated, helpful, and a problem solver.

For future consideration of ZAP Clinic, in several giant beauty companies, there is also a new model named Direct-to-Consumer (D2C) (Kim, Shin, \& Kim, 2021). D2C model is adopted by several giant beauty companies, such as Estee Lauder, L'Oreal, and others. They adopt the new paradigm of a close and direct relationship with customers. To do that effectively, they should overhaul their distribution strategies to make them more relevant to their traditional customers and the new and more demanding generation of consumers.

The D2C model evolves as a response to millennial consumers who are increasingly interested in personal experiences. Their expectations go beyond product features, and they are looking to buy related services that cannot be delivered solely online. These new demands increase experience economy (Kaur \& Kaur, 2020), in which a brand's value lies in the emotions and sensory experiences it triggers and the associated interpersonal relationship. E-commerce will continue to grow steadily, so every beauty company must craft and execute a sound e-commerce business model (Khan, 2016). However, the key to significantly outperforming the market will be to combine an online presence with a well-executed own-brand store strategy.

A D2C strategy can be a powerful growth driver for beauty brands. Although online channels make a substantial contribution, they must be supplemented by own-brand stores because of the growing importance of the experiential economy (Wyman, 2018). A D2C model using physical stores enables brands to better communicate with and deliver products to their customers (Reinartz, Wiegand, \& Imschloss, 2019). In addition, it provides unprecedented access to consumers' essential data for developing a successful consumer-centric business. When consumers buy or almost buy something online, their journey to that purchase is a powerful source of information on their thought processes, habits, and preferences. For example, by setting up a boutique, a brand gains access to the same information to improve its focus on consumers' needs and desires (Wyman, 2018).

\section{CONCLUSIONS}

There is a partial influence between the omnichannel and experiential marketing to the brand association in ZAP Clinic Surabaya. Experiential marketing has a dominant value to create a more positive association with consumers. However, omnichannel can boost the creation of brand association about ZAP Clinic in marketing campaigns and delivering new experiences related to technology in skincare treatment. ZAP Clinic can also maximize and speed up building brand association by adding several sub-components, such as attributes, benefits, and overall evaluation attitude. The finding suggests that in the beauty industry, many strategies are needed to form a brand association and require consistent time and strategy to build a strong and positive brand image.

The limitation of the research is the collection of data with online surveys. The expressions or new insights with open-ended questions to consumers regarding the real experiences they have experienced cannot be observed. This retrieval process is constrained by pandemic conditions so that the research can only find respondents from their social media accounts. So, it is recommended for future research to explore the data using another research design, such as qualitative research. Moreover, as a brand with a main focus in the service sector, future research is suggested to examine more deeply how the four unique factors in services (intangibility, inseparability, variability, and perishability) form a positive brand association in consumers.

\section{REFERENCES}

Blom, A., Lange, F., \& Hess Jr, R. L. (2017). Omnichannelbased promotions' effects on purchase behavior and brand image. Journal of Retailing and Consumer Services, 39(November), 286-295. https://doi. org/10.1016/j.jretconser.2017.08.008

Cook, G. (2014). Customer experience in the omnichannel world and the challenges and opportunities this presents. Journal of Direct, Data and Digital Marketing Practice, 15(4), 262-266. https://doi. org/10.1057/dddmp.2014.16

Ebrahim, R. S. (2020). The role of trust in understanding the impact of social media marketing on brand equity and brand loyalty. Journal of Relationship Marketing, 19(4), 287-308. https://doi.org/10.1080/ 15332667.2019.1705742

Ergin, E. A., Ozdemir, H., \& Ozsacmaci, B. (2006). The effect of brand associations: A field study on Turkish consumers. International Business \& Economics Research Journal (IBER), 5(8), 65-74. https://doi. org/10.19030/iber.v5i8.3499

Ghozali, I. (2016). Aplikasi analisis multivariate dengan program IBM SPSS 23. Badan Penerbit Universitas Diponegoro.

Hasan, A. A. T., \& Hasan, M. (2019). Secondary brand association influences on brand preference and purchase intention. Global Media Journal, 17(32), 1-6.

Hendriyani, C., \& Chan, A. (2018). Understanding the new millennial customer path in the era of omni-channel marketing in Indonesia. Review of Integrative Business and Economics Research, 7(Supplementary Issue 1), 359-367.

Hiraishi, K., Ito, H., Inoue, Y., Eto, K., Katashio, N., Koike, S., ... \& Takahashi, I. (2016). The effect of omni 
channel retailer's strategy on store loyalty. In 2016 SMA Proceedings (pp. 443-449).

Ismail, M. H., Khater, M., \& Zaki, M. (2017). Digital business transformation and strategy: What do we know so far? Cambridge Service Alliance, 10, 1-35. https://doi.org/10.13140/RG.2.2.36492.62086

Kang, J., Majer, M., \& Kim, H. J. (2019). Empirical study of omnichannel purchasing pattern with real customer data from health and lifestyle company. Sustainability, 11(24), 1-16. https://doi.org/10.3390/ SU11247185

Kaur, G., \& Kaur, C. (2020). COVID-19 and the rise of the new experience economy. FIIB Business Review, 9(4), 239-248. https://doi. org/10.1177/2319714520958575

Keller, K. L. (2013). Strategic brand management. Pearson.

Khan, A. G. (2016). Electronic commerce: A study on benefits and challenges in an emerging economy. Global Journal of Management and Business Research, 16(1-B), 19-22.

Kim, N. L., Shin, D. C., \& Kim, G. (2021). Determinants of consumer attitudes and re-purchase intentions toward Direct-To-Consumer (DTC) brands. Fashion and Textiles, 8(1), 1-22. https://doi.org/10.1186/ s40691-020-00224-7

Kim, R. B., \& Chao, Y. (2019). Effects of brand experience, brand image and brand trust on brand building process: The case of Chinese millennial generation consumers. Journal of International Studies, 12(3), 9-21. https://doi.org/10.14254/2071-8330.2019/12$3 / 1$

Kotler, K. (2016). Marketing management. Pearson.

Kumar, V. (2018). Transformative marketing: The next 20 years. Journal of Marketing, 82(4), 1-12. https://doi. org/10.1509/jm.82.41

Lee, W. J. (2020). Unravelling consumer responses to omnichannel approach. Journal of Theoretical and Applied Electronic Commerce Research, 15(3), 37-49. https://doi.org/10.4067/S0718-18762020000300104

Lemeshow, S., Hosmer Jr, D. W., Klar, J., \& Lwanga, S. K. (1990). Adequacy of sample size in health studies. Chichester: John Wiley \& Sons Ltd.

Matzler, K., Eichen, S. F. V. D, Anschober, M., \& Kohler, T. (2018). The crusade of digital disruption. Journal of Business Strategy, 39(6), 13-20. https://doi. org/10.1108/JBS-12-2017-0187

Moustakas, E. (2015). The impact of social networking on consumer behaviour. In ERPBSS Conference.

Nabot, A., Garaj, V., \& Balachandran, W. (2014). Consumer attitudes toward online shopping: An exploratory study from Jordan. International Journal of Social Ecology and Sustainable Development (IJSESD), 5(3), 13-24. https://doi.org/10.4018/ ijsesd.2014070102

Polyakova, O., \& Mirza, M. (2015). Perceived service quality models: Are they still relevant? The Marketing Review, 15(1), 59-82. https://doi.org/10. 1362/146934715x14267608178721
Reinartz, W., Wiegand, N., \& Imschloss, M. (2019). The impact of digital transformation on the retailing value chain. International Journal of Research in Marketing, 36(3), 350-366. https://doi.org/10.1016/j. ijresmar.2018.12.002

Shah, I. A., Rajper, Z. A., Ghumro, I. A., \& Mahar, S. W. (2018). Experiential value mediates relationship between experiential marketing and customer satisfaction. Sukkur IBA Journal of Management and Business, 5(2), 45-61.

Simone, A., \& Sabbadin, E. (2018). The new paradigm of the omnichannel retailing: Key drivers, new challenges and potential outcomes resulting from the adoption of an omnichannel approach. International Journal of Business and Management, 13(1), 85-109. https:// doi.org/10.5539/ijbm.v13n1p85

Sugesti, N. L., Kusniawati, A., \& Prabowo, F. H. E. (2019). Pengaruh omni-channel marketing terhadap minat beli konsumen (Studi kasus pada produk tabungan emas PT. Pegadaian Syariah cabang Padayungan). Business Management and Entrepreneurship Journal, 1(4), 92-101.

Świtała, M., Gamrot, W., Reformat, B., \& BilińskaReformat, K. (2018). The influence of brand awareness and brand image on brand equity - An empirical study of logistics service providers. Journal of Economics and Management, 33(3), 96119. https://doi.org/10.22367/jem.2018.33.06

Syana, A. B. (2019). ZAP Clinic sukses raih Marketeers Omni Brands Award 2019. Retrieved from https:// www.marketeers.com/zap-clinic-sukses-raihmarketeers-omni-brands-award-2019/

Taherdoost, H. (2016). Sampling methods in research methodology; How to choose a sampling technique for research. SSRN Electronic Journal, 5(2), 18-27.

Teixeira, T. S. (2019). Disruption starts with unhappy customers, not technology. Retrieved from https:// hbr.org/2019/06/disruption-starts-with-unhappycustomers-not-technology?referral $=03759 \& \mathrm{~cm}$ $\mathrm{vc}=\mathrm{rr}$ _item_page.bottom\%0Ahttps://hbr. org/2019/06/disruption-starts-with-unhappycustomers-not-technology

Wirtz, B. W., \& Daiser, P. (2018). Business model development: A customer-oriented perspective. Journal of Business Models, 6(3), 24-44. https://doi. org/10.5278/ojs.jbm.v6i3.2031

Wyman, O. (2018). Building a $\$ 10$ billion beauty brand through boutiques: Why physical retail is important in an online era. Retrieved from https://www. oliverwyman.com/content/dam/oliver-wyman/v2/ publications/2018/February/R\&C-Journal-vol6Beauty.pdf

Yanuardi, A. W., Wahyudi, W. T., \& Nainggolan, B. (2016). Analisis omnichannel customer experience maturity di PT. Telekomunikasi Indonesia. Jurnal Manajemen Indonesia, 16(2), 81-94. https://doi.org/10.25124/ jmi.v16i2.314

ZAP Clinic. (2020). ZAP beauty index. Retrieved from https://zapclinic.com/zapbeautyindex 